По-четверте, виникнення поки ще невеликого прошарку успішного інноваційного співтовариства (наука + бізнес), що бачить своє майбутнє у якості рівноправного партнера світового інноваційного процесу.

Висновок. Аналіз розвитку світового господарства в останні 50 років показує, що перехід вітчизняної економіки на інноваційний алгоритм розвитку найбільш вірогіден при паралельній реалізації чотирьох складових: ефективної організації наукових досліджень, що дозволяють зберегти i розширити області, у яких українська наука займає провідні позиції; технологічній модернізації вітчизняної промисловості; будуванні сучасного високотехнологічного агропромислового комплексу; створенні національної і регіональних інноваційних систем, включаючи інноваційну інфраструктуру, що забезпечує ефективну комерціалізацію знань, як наукових, так і знань іншого походження.

Перший напрямок - удосконалення організації наукової діяльності, іiі правової, фінансово-економічної й інституціональної складових - практично цілком відноситься до компетенції центральних органів влади держави і тому виходить за межі відповідальності регіонів. Докорінна структурнотехнологічна модернізація промисловості та відновлення на новій основі ефективного агропромислового комплексу також значною мірою $\epsilon$ проблемами національного масштабу, хоча в цьому напрямку в регіонів також є свої ресурси і можливості. А от четвертий ключовий напрямок формування інституцій інноваційної системи - може реалізовуватися i розвиватися як за рахунок ресурсів i повноважень центральних, так i регіональних органів влади і місцевого самоврядування. Тому, приймаючи стратегію інноваційного розвитку регіону і виробляючи відповідну програму, в першу чергу доцільно сконцентруватися на четвертому напрямку i розглядати створення регіональної інноваційної системи як найважливішу умову становлення і розвитку інноваційної економіки.

Надійшла (received) 05.10.2014

L. S. CHERNOVA, Master's Degree Student of the Project Management Department, Admiral Makarov National University of Shipbuilding, Nikolaev

\title{
DIVERSIFICATION OF MARKET FOR THE UKRAINIAN GAS TURBINE BUILDING AS A KEY FACTOR OF PRODUCTION STABILIZATION IN THE MODERN CONTEXT
}

The article presents the analysis and studying of prospective domestic and external markets for SE "Zorya"-"Mashproekt" GTR\&PC's products in relation to the current trends of gas turbine industry

(C) L. S. Chernova, 2015 
development in various directions. In addition to the existing markets, in which the products of the above enterprise are present, the prospective alternatives for penetration into the world markets are discussed, as well as participation in the domestic market with consideration for the required diversification not only for SE "Zorya"-"Mashproekt" GTR\&PC, but also for the whole gas turbine industry of Ukraine.

Keywords: diversification of market, gas turbine industry, power generating GTU, general purpose industrial GTE, marine GTE, mechanical drive market.

Introduction. The annual volume of sales of gas turbine equipment during the period from 2009 to 2013 comes to about 16-22 billion of US dollars. The volume of power-generating GTEs in the mentioned period of time is $83 \%$ (or 16.3 billion of US dollars/year), mechanical drive - 15\% (or 2.9 billion of US dollars/year), and marine GTEs - 2\% (or 396 billion of US dollars/year).

The leaders of the world GTE sales market are the following companies: Solar (2377 units), General Electric (1669 units), Siemens (863 units), SE "Zorya""Mashproekt" GTR\&PC (379 units), Rolls-Royce (255 units), OKSC "Perm Engine Company" (204 units), Pratt\&Whitney (166 units).

Problem. Before the year of 2014 the Russian market of GTEs was the most significant for SE “Zorya"-"Mashproekt" GTR\&PC's products (30-50\% of annual production output), but in 2014, due to certain political events, the major portion of the Russian market was frozen. Decline in the volume of sales to the Russian customers has an adverse effect on the Enterprise's production development, which urges towards intensification of marketing efforts aiming to seek new target product markets.

Objectives. Analysis of domestic and external GTE markets (except for Russia) for the period from 2009 to 2013 shows that the demand for the gas turbine equipment in the world remains stable, giving a chance to SE "Zorya""Mashproekt" GTR\&PC not only to build its business in markets, which have been developed to some degree (i.e. India, China, Kazakhstan, Uzbekistan and Near East), but also to penetrate into new markets of some countries of Southeast Asia, Africa and Latin America. An additional possibility to increase the volume of sales of SE "Zorya"-"Mashproekt" GTR\&PC's products may be provided by the domestic market, namely through participation in the program for renovation of the gas transportation system of Ukraine.

Methods and Results. Determination of the perspectives and methods of objectives pursuing is grounded on the analysis of condition of the internal and foreign (except for the Russian one) markets.

For example, the major consumers of general purpose industrial GTEs are Russia, USA, Iran, Chine, Saudi Arabia, and India. The leaders of world market of general purpose industrial GTEs are such companies as Solar, General Electric, Siemens, SE "Zorya"-"Mashproekt” GTR\&PC, Rolls-Royce, OJSC "Perm Engine Company", and Pratt \&Whitney. 
The world market of power generating GTUs during the period 2009 through 2013 remained stable and came to 800-920 units/year (fig.1).

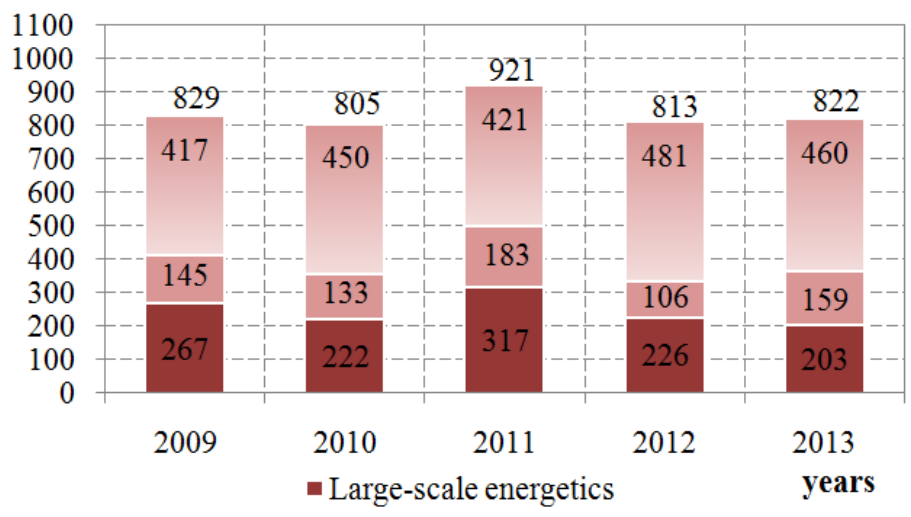

Figure 1 - State of world market for power generating GTUs in 2009-2013

The power generating world market of low-power GTUs (2-30 MW) should be empathized as well. The major consumers of low-power gas turbine power generating equipment in this market are gas-producing and oil companies that employ the GTUs as a part of electric power station for own needs.

In the mentioned market the major competitors of SE "Zorya"-"Mashproekt" GTR\&PC are General Electric Co. and Solar Co. (USA) being an undisputed leader in supplying of power-producing gas turbine equipment (59\%), Pratt \& Whitney (Canda), Siemens (Germany), Rolls-Royce (the United Kingdom), OJSC "Perm Engine Company", OJSC "UEC-Gas Turbines" (in the past "Saturn-Gas Turbines") and KMPO (Russia).

Some features of interest are presented by the market of power generating GTUs rated at 45-60 MW. In 2009-2013 in this segment three types of engines are dominant ones: LM6000 by General Electric Co.; SGT-800 by Siemens Co. and Trent-60 by Rolls-Royce Co. The main sales markets for such types of GTUs are the USA (64 units), Thailand (28 units), Russia (26 units), Israel (16 units), and Germany (15 units).

The market for mechanical drive GTUs in recent years remains quite stable and comes to 370-490 units/year. The main competitors of SE "Zorya""Mashproekt" GTR\&PC in this world market are the following companies: General Electric and Solar (USA), Siemens (Germany), Rolls-Royce (the United Kingdom), OJSC "Perm Engine Company" and KMPO (Russia).

During the period from 2009 - 2013 in the market of marine GTEs 72 war ships were constructed, abroad which 234 GTEs were installed. The portion of SE "Zorya"-"Mashproekt" GTR\&PC amounts to 47\% of the marine GTEs market (fig. 2). 


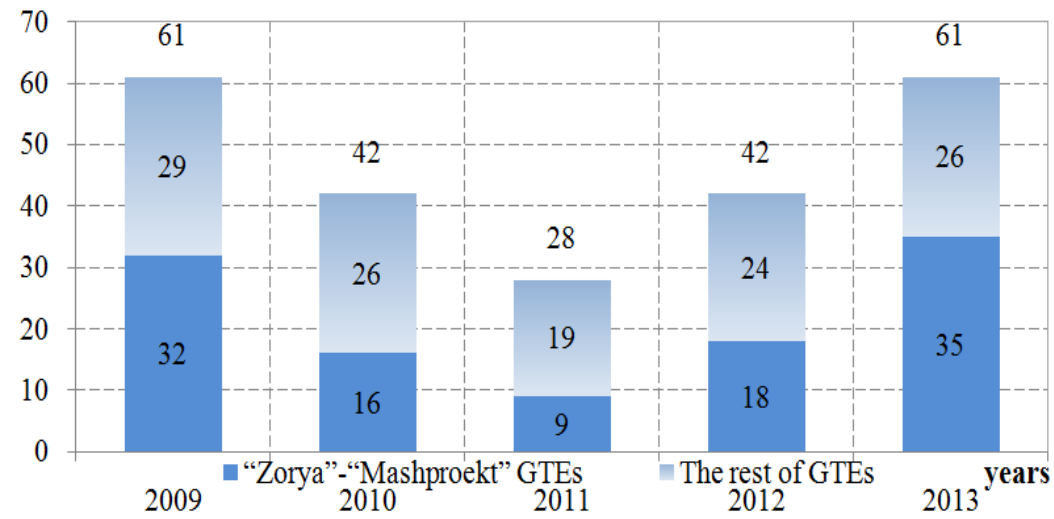

Figure 2 - State of marine GTEs market in 2009-2013

The leader in supplies of marine GTEs is LM2500 engine manufactured by General Electric Co., but in the year of 2013 SE "Zorya"-"Mashproekt" GTR\&PC has significantly strengthened its presence in the market of marine GTEs due to the considerable growth of export supplies of war ships constructed by Russia into the world arms market.

We can now return to the domestic market of gas turbine machinery. In the present moment, the situation in Ukraine is destabilized and the investment climate in the country is extremely unfavorable. However, in recent times the international foreign banks such as: International Bank for Reconstruction and Development (IBRD) and European Bank for Reconstruction and Development (EBRD) plan to actively render assistance to Ukraine via their projects.

Participation of SE "Zorya"-"Mashproekt" GTR\&PC in international programs for improving energy effectiveness of Ukraine provides possibility for the company to assure the internal (domestic) market.

In addition, SE "Zorya"-"Mashproekt" GTR\&PC is one of the world's leading companies manufacturing marine and industrial gas turbine engines and equipment rated at 2.5 through $25 \mathrm{MW}$ and covers $6.4 \%$ of GTUs world market.

Conclusion. The problem of decline in the volume of sales to the Russian market is topical for a number of Ukrainian turbine-manufacturing plants (including SE "Zorya"-"Mashproekt" GTR\&PC) which were mainly oriented towards the Russian customer before the year of 2014.

A steady global demand forecasted for gas turbine equipment can allow SE "Zorya"-"Mashproekt" GTR\&PC to solidify its market position in India, China, Kazakhstan, Uzbekistan and Near East, as well as to penetrate into new markets of some countries of Southeast Asia, Africa and Latin America. 
Internal market can offer an additional possibility to increase sales amount of gas turbine equipment; it particularly concerns the prospective modernization of the Ukrainian gas transportation system provided that the state policy is guided towards purchasing of domestic production.

On the assumption of an optimum marketing policy and conditioned upon favourable circumstances, the loss of the Russian market may be compensated within 3-5 years. The discussed tendencies are of great importance for the whole gas turbine building industry of Ukraine.

Received 05.12.2014

\section{УДК 519.2}

В. В. МОРОзОВ, канд. техн. наук, професор, зав. каф., Університету економіки та права «КРОК», Київ;

Ю. О. ЛЮБИМА, аспірант, Університету економіки та права «КРОК», Київ

\section{ОСОБЛИВОСТІ УПРАВЛІННЯ ПОРТФЕЛЕМ ПРОЕКТІВ РОЗВИТКУ НАУКОМІСТКИХ ІННОВАЦІЙНИХ ПІДПРИЕМСТВ В ОБЛАСТІ НАНОБІОТЕХНОЛОГІЙ}

Визначені основні особливості реалізації проектів в області нанобіотехнологій, які істотно впливають на управління наукомісткими проектами. Показана необхідність залучення методів управління проектами при реалізації інноваційних проектів для їх найшвидшого впровадження в найбільш перспективних галузях народного господарства.

Ключові слова: портфелі проектів, інноваційні проекти, нанобіотехнології, мікроелементи, управління проектами.

Вступ. Сучасний стан розвитку технологій управління проектами та програмами характеризується їх подальшим вдосконаленням і застосуванням у різних галузях. Це стосується і галузі діяльності наукових підприємств, де виживання та подальший розвиток підприємств у сучасному кризовому i турбулентному оточенні $\epsilon$ вкрай важливим. Дана стаття присвячена дослідженням впровадження технологій управління проектами для сталого розвитку наукових підприємств за рахунок ефективних заходів щодо формування та управління портфелем проектів.

Постановка проблеми. Зростання населення земної кулі і підвищення життєвого рівня в ряді регіонів планети неминуче веде до розширення споживчого попиту i, як наслідок, до збільшення промислового i

(C) В. В. Морозов, Ю. О. Любима, 2015 